\title{
Світлана Нижнікова
}

(Харківський національний університет імені В.Н. Каразіна, Харків)

\section{Навчальний процес в єпархіальних жіночих училищах Російської імперії (друга половина XIX - початок XX ст.)}

\author{
Educational Process in the Eparchial Women's Schools in the Russian Empire \\ (Second Half of the $19^{\text {th }}-$ Early $20^{\text {th }}$ Centuries)
}

РЕЗЮME

У статті проаналізовано навчальний процес в епархіальних жіночих училищах та його зміни протягом другої половини XIX - початку XX ст. Відзначається, що навчальний процес епархіальних училищ знаходився під впливом соціокультурних та політичних чинників. Вперше досліджено проект статуту єпархіальних училищ 1915 р.

Ключові слова: історія освіти, училища для дівиць духовного звання, єпархіальні жіночі училища, навчальний процес

Єпархіальні жіночі училища були важливим сегментом системи освіти в Російській імперії в XIX - на початку XX ст. Ці освітні інституції пройшли складний шлях трансформацій під впливом реформ та контрреформ протягом другої половини XIX ст. Спархіальні училища були засновані як закриті станові навчальні заклади 3 метою виховання «гідної дружини служителя вівтаря Божого та дбайливої матері»ํ. У 1918 р., на момент їх ліквідації радянською владою, вони були напівзакритими всестановими училищами, завданням яких була підготовка вчитедьок початкової школи. Всього у період з 1843

${ }^{1}$ Полное собрание законов Российской империи [dalej: ПСЗРИ], t. 18, Sankt Petersburg 1843, s. 528 . 
по 1918 рр. у Російській імперії функціонувало 71 єпархіальне жіноче училище.

Метою цього дослідження є виявлення специфіки навчального процесу єпархіальних жіночих училищ протягом другої половини XIX - початку XX ст. та його еволюції. Хоча існує низка досліджень, присвячених окремим аспектам історії єпархіальних жіночих училищ, втім навчальний процес досі не ставав предметом спеціальної уваги. Між тим, вивчення цих училищ важливо для дослідження як історії освіти, зокрема жіночої, так і гендерних аспектів культури. Навчальний процес єпархіальних училищ можливо реконструювати, спираючись, передовсім на законодавчі та актові джерела, діловодну документацію єпархіальних жіночих учидищ.

Перше училище для дівчат духовного стану було відкрито у Царському селі в 1843 р. Протягом наступних років училища подібного типу були засновані у більшості епархій². Діяльність цих освітніх установ регламентувалася статутом для дівчат духовного звання, який був затверджений 1843 р. Училища були навчальними закладами закритого типу, й призначалися виключно для дівчат духовного стану. В училищах викладали Закон Божий, читання і письмо російською мовою, арифметику, чистописання і малювання, російську граматику і словесність, російську історію і географію, всесвітню історію і географію в скороченому вигляді, нотний церковний спів і рукоділля. Навчальний курс був шестирічний і був поділений на три класи: нижчий, середній і вищий. Крім того, важливою складовою навчання було надання вихованкам знань та навичок ведення домашнього господарства. Акцент на домашньому господарстві був зумовлений тим, що це було затребуване у майбутньому житті кожної учениці. Вихованок навчали випікати хліб і проскури, готувати різноманітні продукти на зиму. Дівчата отримували знання із садівництва та городництва ${ }^{3}$.

Аналіз навчального плану училищ для дівиць духовного звання Російської імперії у другій половині 1840-х - 1860-х рр. засвідчив, що він не був тотожним планам інших жіночих навчальних закладів та чоловічим духовним семінаріям. Перелік навчальних дисциплін в жіночих духовних училищах не включав ряд предметів, що викладали в жіночих навчальних закладах Маріїнського відомства: нові мови, музика, фізика, природознавство. У чоловічих духовних семінаріях учні

\footnotetext{
${ }^{2}$ Об учихищах девиц, ууховного звания, Sankt Petersburg 1866, s. 98-99.

${ }^{3}$ И. Чижевский, Харьковское епархиальное училище в пятидесятый год его существования, Charków 1904, s. 13.
} 
вивчали латину, грецьку мову, хімію, фізику, природознавство, логіку, психологію тощо. Таким чином, навчальний курс жіночих духовних училищ від початку їх заснування був дещо скороченим у порівняні 3 жіночими училищами Маріїнського відомства і Міністерства народної освіти.

Аналізуючи навчальний план училищ для дівиць духовного стану у 1840-1850-ті роки, варто відзначити, що хоча у статуті 1843 р. було задекларовано, що метою навчання в училищах була підготовка майбутніх дружин священнослужителів, на практиці вихованки отримували знання лише із загальноосвітніх дисциплін. Церковне керівництво не ініціювало впровадження курсів, які б надавали дівчатам спеціальні чи поглиблені знання з богословських дисциплін. Єдиною релігійно-орієнтованою дисципліною у навчальному курсі училищ був Закон Божий. Однак цей предмет був обов'язковим для всіх учнів православного віросповідання початкової і середньої школи. Наприклад, у жіночих гімназіях цей курс вивчали всі сім років, зазвичай, по два уроки на тиждень ${ }^{4}$, а в училищах для дівчат духовного звання - по три уроки на тиждень ${ }^{5}$.

Перетворення 1860-х років торкнулися практично усіх сфер життя Російської імперії. Церква намагалася подолати замкненість, притаманну духовному стану в цілому і духовній освіті зокрема6 ${ }^{6}$ Як наслідок, у 1867-1869 рр. було проведено широкомасштабне реформування чоловічої та жіночої духовної освіти. 20 вересня 1868 р. був затверджений Статут єпархіальних жіночих училищ. Цим актом училища для дівиць духовного звання були перейменовані в єпархіальні жіночі училища та реорганізовані у напівзакриті всестанові навчальні заклади. Були суттєво розширені завдання цих освітніх установ. Відтепер вони мали на меті не тільки підготовку майбутніх дружин священнослужителів, а й вчительок початкової школи. Після реорганізації єпархіальні училища могли бути шестикласними 3 річним курсом навчання у кожному класі або трикласними при дворічному навчальному курсі ${ }^{7}$.

Відповідаючи на запити часу, було розширено навчальний курс єпархіальних училищ. За статутом 1868 р. єпархіалки мали вивча-

${ }^{4}$ Т.Б. Котлова, Социиокультурная среда в российском провинцุиальном городе в конце XIX - начале XX века: гендерный аспект, Iwanowo 2001, s. 100.

${ }^{5}$ Российский государственный исторический архив [dalej: РГИА], zesp. 802, inw. 8, sygn. 24618, k. 4.

${ }^{6}$ С. Кучерова, Загальноосвтній аспект програм духовних навчальних закладів (аналіз статутів 60-х рр. ХІХ ст.), „Сіверянський літопис” 2003, 4, s. 117.

${ }^{7}$ ПСЗРИ, t. 43, Sankt Petersburg 1868, s. 259. 
ти Закон Божий, російську мову, теорію словесності, російську і всесвітню історію та географію, математичні дисципліни (арифметику, основи геометріі), фізику, чистописання, педагогіку, церковний спів та церковнослов'янську мову ${ }^{8}$ У навчадьних розкладах з'явилися і необов' язкові предмети, які викладади за додаткову платню. До них відносилися «нові мови» (французька та німецька), малювання та музика. Заняття домашнім рукоділдям у відповідності до статуту 1868 р. мали бути виключені з навчальних розкладів та перенесені до позаурочного часу. Отже, вихованки цих освітніх інституцій здобувади в процесі навчання різноманітні знання загальноосвітнього характеру9. Були розроблені й затверджені короткі навчальні програми, які містили лише загальні рекомендації щодо матеріалу, який необхідно було прочитати в кожному класі ${ }^{10}$. Складання детальних програм 3 кожного предмету статут покладав на викладачів училищ. Це надавало викладачам певний простір для експериментів, мождивості для використання місцевих особливостей.

Після закінчення навчального року епархіалки повинні були скласти відповідні іспити. Оцінювання знань вихованок відбувалося за п'ятибальною системою. Підсумкова оцінка виводилася в результаті здійснення ряду операцій. За чвертями в єпархіальних училищах проходиди атестації. Наприкінці навчадьного року на їх підставі виставлялася річна оцінка. Після закінчення навчальних занять вихованки з усіх предметів складади річні іспити. Як правило, іспити приймалися комісією у складі начальниці училища, інспектора класів, одного з членів ради від духовенства і викладача відповідного предмету. Інколи на іспитах були присутні єпископи, попечителі навчальних округів, представники повітової земської управи, міської думи. Екзаменаційна оцінка виводилася в такий спосіб: середне арифметичне суми балів усіх екзаменаторів. Підсумковий бал ставився як середне арифметичне суми річної й екзаменаційної оцінок.

Отже, реформа єпархіальних училищ у 1868 р. була спрямована на розширення викладання саме загальноосвітніх дисциплін. Приймаючи новий статут єпархіальних училищ, реформатори намагадися пододати відставання церковної шкоди від світської щодо обсягів загальноосвітнього компоненту, максимально наблизити навчальну програму єпархіальних училищ до міністерських та маріїнських

\footnotetext{
${ }^{8}$ Ibidem, s. 259-260.

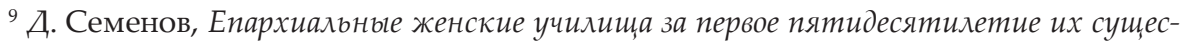
твования, „Русская школа" 1893, 9-10, s. 30.

${ }^{10}$ Ежегодник правил приема и программ всех учебных заведений. 1900-1901 учебный год. Вып. 23: Епархиальные женские училища, Sankt Petersburg 1899, s. 14-19.
} 
навчальних закладів. Слід підкреслити, що в середині XIX ст. світська середня жіноча освіта розвивалася набагато динамічніше за церковну, отже вона мала й дійсно стала зразком для перетворень.

Таблиця 1. Навчальні плани жіночих середніх навчальних закладів Російської імперії

\begin{tabular}{|c|c|c|c|c|}
\hline $\begin{array}{c}\text { Навчальні } \\
\text { курси / Навчальні } \\
\text { заклади }\end{array}$ & $\begin{array}{c}\text { Єпархіальні } \\
\text { жіночі } \\
\text { училища, } \\
1868 \text { р., } \\
\text { загальна } \\
\text { кількість } \\
\text { годин з курсу } \\
\text { на тиждень }\end{array}$ & $\begin{array}{c}\text { Гімназії } \\
\text { Міністерства } \\
\text { народної освіти, } \\
1870 \text { р., } \\
\text { загальна } \\
\text { кількість годин } \\
\text { з курсу на } \\
\text { тиждень }\end{array}$ & $\begin{array}{c}\text { Гімназії } \\
\text { Відомства } \\
\text { установ } \\
\text { імператриці } \\
\text { Марії, } 1863 \text { р., } \\
\text { загальна } \\
\text { кількість } \\
\text { годин з курсу } \\
\text { на тиждень }\end{array}$ & $\begin{array}{c}\text { Інститути } \\
\text { Відомства } \\
\text { установ імпера- } \\
\text { триці Марії, } \\
1855 \text { р., загальна } \\
\text { кількість годин } \\
\text { з курсу } \\
\text { на тиждень }\end{array}$ \\
\hline Закон Божий & 21 & 14 & 17 & 18 \\
\hline $\begin{array}{l}\text { I. Гуманітарні } \\
\text { предмети }\end{array}$ & 42 & 97 & 101 & 108 \\
\hline $\begin{array}{l}\text { Російська мова, } \\
\text { церковно-слов’янська } \\
\text { мова, теорія } \\
\text { словесності }\end{array}$ & 21 & 23 & 25 & 18 \\
\hline Французька мова & 0 & 26 & 28 & 27 \\
\hline Німецька мова & 0 & 26 & 23 & 27 \\
\hline Історія & 9 & 12 & 11 & 18 \\
\hline Географія & 12 & 10 & 14 & 18 \\
\hline $\begin{array}{l}\text { II. Природничо- } \\
\text { математичні } \\
\text { предмети } \\
\end{array}$ & 25 & 33 & 33 & 18 \\
\hline Математика & 20 & 23 & 15 & 9 \\
\hline Фізика & 5 & 10 & 18 & 9 \\
\hline $\begin{array}{r}\text { III. Графічні } \\
\text { предмети } \\
\end{array}$ & 10 & 20 & 23 & 27 \\
\hline Чистописання & 10 & 6 & 9 & \multirow{2}{*}{27} \\
\hline Малювання & 0 & 14 & 14 & \\
\hline IV. Інші предмети & 10 & 11 & 36 & 15 \\
\hline Педагогіка & 2 & 2 & 4 & 0 \\
\hline Співи & 12 & 0 & 14 & 0 \\
\hline Рукоділля & 0 & 9 & 13 & 0 \\
\hline Танці & 0 & 0 & 5 & 0 \\
\hline $\begin{array}{l}\text { Загальна кількість } \\
\text { годин на тиждень }\end{array}$ & 112 & 175 & 210 & 171 \\
\hline Термін навчання & 6 & 7 & 7 & 6 \\
\hline
\end{tabular}

Джерело: Э.Д. Днепров, Среднее женское образование в России. Учебное пособие, Moskva 2009, s. 212. 
1880-ті роки у Російській імперії були періодом посилення політичної реакції. У 1884 р. було затверджено «Правила о церковнопарафіяльних школах», що призвело до масового відкриття церковнопарафіяльних шкіл, які фінансувалися урядом. Мета цих дій полягала в тому, щоб посилити державний вплив на початкову народну освіту. 3 особливою гостротою постала проблема кадрового забезпечення церковнопарафіяльних шкі $\AA^{11}$.

Одним із рішень цієї проблеми стало внесення у 1886 р. Навчальним комітетом при Св. Синоді ряду змін у навчальний процес епархіальних жіночих училищ. У першу чергу курс педагогіки був замінений курсом дидактики, в якому набагато більше уваги приділялося практиці педагогічної роботи, а також навчанню методиці викладання у початковій школі. Крім того, Навчальний комітет при Св. Синоді рекомендував відкрити зразкові церковнопарафіяльні школи при училищах, в яких вихованки п'ятих і шостих кдасів мади проходити педагогічну практику. Протягом 1880-1890-х рр. при більшості єпархіальних училищ були відкриті церковнопарафіяльні школи. Вони стали базою для педагогічної практики єпархіалок. Саме у цих шкоиах вихованки мали погдибити і закріпити теоретичні знання, отримані в училищах, навчитися застосовувати їх у навчально-виховній роботі з учнями. Важдивою новацією реформи була рекомендація щодо створення підготовчого класу при кожному єпархіальному училищі. 3 метою допомоги дівчатам сформувати базовий запас знань для вступу до першого класу ${ }^{12}$. Однак, як показала історія, втілення в життя цієї статті постанови 1886 р. розтягнулося аж до кінця століття. Параграфи, які стосувалися відкриття зразкових церковнопарафіяльних шкіл і підготовчих класів, носили рекомендаційний характер, оскільки на їх реалізацію були потрібні кошти. Відзначимо, що всі єпархіальні училища утримувалися виключно на кошти відповідних єпархій і напряму залежали від місцевих можливостей. Отже, 1886 р. можна вважати початком нового етапу розвитку єпархіальних жіночих училищ. Зміни, що відбулися, були спрямовані на підвищення рівня педагогічної підготовки єпархіалок.

Значною віхою в розвитку учидищ було затвердження у 1895 р. нових єдиних навчальних програм для всіх єпархіальних жіночих училищ. У цих програмах було детально визначено обсяг і зміст

${ }^{11}$ O.О. Драч, Розвиток початкової освіти в Україні (1861-1917 рр.), Charków 2001, s. 43-44.

12 Определение Св. Синода от 30 июля - 12 августа 1886 года, „Вера и разум” 1886, 17, s. 391-394. 
курсу кожного навчального предмету ${ }^{13}$. Постановою Св. Синоду від 3 - 10 липня 1896 р. ці програми було дозволено запроваджувати поступово, починаючи з першого класу ${ }^{14}$.

На початку XX ст. за рівнем підготовки вихованок єпархіальні жіночі училища значно відставали від жіночих гімназій, навчальний курс яких був семирічний і додатково відкривалися восьмі педагогічні класи. Крім того, перелік дисциплін в єпархіальних училищах не змінювався 31868 р, якщо не враховувати заміни педагогіки дидактикою у 1886 р. Між тим, життя йшло вперед, і єпархіалки все більше відчували недостатність тих знань, що надавали їм у єпархіальних училищах. Наприкінці XIX ст. почастішали подання до Св. Синоду скарг, в яких начальниці єпархіальних училищ писали, що при прийнятті на роботу перевага надавалася випускницям жіночих гімназій ${ }^{15}$. Не випадково, що й у періодиці того часу активно обговорювалося питання про якість освіти, яку отримували в єпархіальних училищах і необхідність реорганізації навчального процесу в цих закладах ${ }^{16}$.

Під час революції 1905-1907 рр. заворушення охопили і єпархіальні жіночі училища. Анадіз документів Св. Синоду дозволяє стверджувати, що найпоширенішим способом вираження невдоволення вихованців духовно-навчальних закладів були петиції. Епархіальними училищами також прокотилася хвиля незадоволення, яка мала прояв передовсім у поданні петицій до учидищних рад та до Св. Синоду ${ }^{17}$. Вимоги єпархіалок були вельми схожими з вимогами семінаристів. На першому місці у всіх петиціях була зазначена необхідність реформи всієї системи єпархіальних училищ. Укладачі петицій мали на увазі ліквідацію станового устрою, зрівняння в правах випускниць єпархіальних та жіночих і чоловічих гімназій. У петиціях йшлося про необхідність надання єпархіалкам права вступати до усіх вищих чоловічих та жіночих навчальних закладів як спеціального, так і загальноосвітнього характеру ${ }^{18}$.

${ }^{13}$ Определение Св. Синода от 6-28 сентября 1895 года за № 2689, „Церковные ведомости" 1895, 40, s. 371-372.

14 Определение Св. Синода от 3-10 июля 1896 года, „Церковные ведомости” 1896, 29, s. 296.

${ }^{15}$ РГИА. zesp. 802, inw. 10, sygn. 101, k. 23.

16 Е. Капралова, О новой задачи для епархиальных училищ, „Церковный вестник” 1904, 35, С. 1100-1102; Чего можно желать от епархиальных женских училищ, „Церковный вестник" 1904, 52, С. 1649-1650; И. Филевский, К вопросу о преобразовании нынетнего епархиального женского учихища, „Южный край” 3 X 1905, s. 4.

${ }^{17}$ О.Д. Попова, Петицчии воспитанников духовной школь как выражение общественной мысли в годы первой русской революциии, „Вестник Саратовского государственного социально-экономического университета" 2007, 17(3), s. 172-173.

${ }^{18}$ РГИА, zesp. 802, inw. 10, sygn. 76, k. 32. 
Примітно, що ради навчальних закладів, порушуючи всі правила, приймали ці петиції і навіть розглядали їх. Ради деяких єпархіальних училищ навіть підтримали окремі пропозиції. Натомість Св. Синод засудив подання петицій до училищних рад, оскільки це було порушенням встановленого порядку. Керівництву єпархіальних учидищ було наказано не приймати більше подібних вимог ${ }^{19}$. Між тим, усім радам духовно-навчальних закладів було запропоновано до 1 березня 1906 р підготувати докладні міркування щодо змін в устрої цих училищ ${ }^{20}$. Про результати роботи училищних рад можна дізнатися із матеріалів тритомної справи «Об изменениях в учебно-воспитательном отношении епархиальных женских училищ», яка була сформована в Навчальному комітеті Св. Синоду. У цій справі в алфавітному порядку буди підшиті 58 проектів, надіслані з єпархіальних училищ Російської імперії ${ }^{21}$ У тому ж році усі пропозиції були узагальнені та опубліковані окремою брошурою 22 . Вона є важливим джерелом для вивчення навчального процесу та тих змін, до яких прагнули на місцях.

Усі вимоги училищних рад можна об'єднати у чотири групи: навчальні, адміністративні, виховні і господарські. Найбільше уваги в них приділялося саме навчальній частині. Усі без виключення училища вимагали збільшити термін навчання до семи років і створити восьмий додатковий клас, при можливості дворічний. Крім того, керівництво усіх учидищ сходидося на думці, що зміст та обсяг навчального курсу мали бути зрівняні 3 навчальним курсом міністерських жіночих гімназій. Це передбачало введення нових дисциплін, а також розширення переліку необов' язкових предметів. Один із ключових пунктів усіх петицій та подальших проектів стосувався зрівняння в правах випускниць єпархіальних училищ з випускницями жіночих гімназій ${ }^{23}$.

Розгдянувши ці проекти Св. Синод прийняв кілька важдивих рішень. 1 жовтня 1907 р. було затверджено «Положение о седьмом дополнительном педагогическом классе при епархиальных женских

${ }^{19}$ Определение Св. Синода от 20 декабря 1905 г. за № 6599, по поводу коллективных заявлений воспитаннии, некоторых епархиальных женских училищ, „Церковные ведомости" 1906, 1, s. 8-9.

${ }^{20}$ Определение Св. Синода от 20-22 декабря 1905 года за № 6598, по делу о преобразовании епархиальных женских училищ, „Церковные ведомости” 1906, 1, s. 7-8.

${ }^{21}$ РГИА. zesp. 802, inw. 10, sygn. 57, 351 s.

${ }_{22}^{22}$ Извлечения из представленных епархиальныли преосвященными святейшему Синоду соображений советов епархиальных женских училищ, по вопросу об изменениях, желательных в строе этих училищ, Sankt Petersburg 1906, 31 s.

${ }^{23}$ Ibidem, s. 11-17. 
училищах». Навчальний курс цього класу був розрахований на один або два роки. Навчання в сьомому додатковому класі було спрямоване на підвищення загального рівня знань вихованок і більш поглиблену підготовку до вчителювання ${ }^{24}$. Крім того, Навчальний комітет при Св. Синоді реформував навчальні програми. Були включені нові загальноосвітні дисципліни: природознавство і креслення, а малювання та рукоділля були перенесені з необов' язкових у розряд обов' язкових курсів, були дещо змінені рекомендації щодо підручників. Кількість годин з деяких загальноосвітніх дисциплін була збільшена. Так, викладання алгебри та геометрії було збільшено на шість годин на тиждень, історії російської дітератури - на п'ять годин, російської мови та історії - на чотири години, дидактики та фізики - на одну годину. Було зменшено години, відведені на викладання Закону Божого, арифметики, географії та чистописання ${ }^{25}$.

Ці зміни суттєво вплинули на якість навчальної програми та підвищили рівень підготовки вихованок в єпархіальних училищах. Водночас випускниці єпархіальних учидищ так і не були зрівняні у правах 3 випускницями жіночих гімназій, у тому числі вони не отримали право на вступ до вищих навчальних закладів. У 1912-1913 рр. до Навчального комітету при Св. Синоді знову почади надходити скарги на недостатній рівень підготовки єпархіадок від керівництва училищ ${ }^{26}$.

У лютому 1915 р. був розроблений проект нового статуту єпархіальних жіночих училищ за новими нормами. Було розширено строк навчання до семи років і при всіх єпархіальних учидищах мав бути створений восьмий додатковий педагогічний клас. Було ускладнено вимоги до вступних іспитів. Перелік обов'язкових дисциплін відтепер вкдючав Закон Божий, церковний спів, російську та церковнослов' янську мови, теорію словесності, історію російської літератури, математику, фізику, історію, природознавство, географію, космографію, французьку та німецьку мови, педагогіку й дидактику, чистописання, малювання, рукоділля, гігієну і гімнастику. До необов'язкових предметів відносилися иатина, музика, іконописання, медицина, сільське господарство і стенографія. Восьмий педагогічний клас мав поділятися на чотири відділи: словесно-історичний, фізико-математичний, природничо-географічний та відділ нових

${ }^{24}$ Определение Св. Синода от 10-11 октября 1907 2. за № 6394, о Высочайшем утверждении положения о седьмом дополнительном педагогическом классе при епархиальных женских училищах, „Церковные ведомости” 1907, 41, s. 368.

${ }^{25}$ Определение Св. Синода от 23 августа - 5 сентября 1907 года, „Церковные ведомости" 1907, 36, s. 326.

${ }^{26}$ РГИА, zesp. 802, inw. 11, sygn. 20, k. 5, 5v, k. 6. 
мов $^{27}$. Текст проекту цього статуту свідчить, що Св. Синод мав наміри провести значні реформи в галузі духовної освіти. Однак новий статут так і не вдалося запровадити. Реводюційні події, що почалися у 1917 році, призвели до ліквідації такого типу навчальних закладів.

Таким чином, навчальний процес у єпархіальних жіночих училищах Російської імперії протягом другої половини XIX - початку $\mathrm{XX}$ ст. не був незмінним і зазнав ряд перетворень. На першому етапі, у 1840-ті рр. - 1868 р., сформувалася мережа училищ для дівиць духовного звання. У порівнянні із жіночими училищами та інститутами шляхетних дівчат навчальний курс єпархіальних училищ був дещо спрощеним та скороченим. Для другого періоду, 1868 - 1907 рр., характерна тенденція до погдиблення педагогічної освіти, що надавали епархіалкам. Це мало прояви у заміні курсу педагогіки курсом дидактики та залученням вихованок до практичної педагогічної роботи. У 1907-1918 рр. реформування навчального процесу було спрямоване на розширення та збільшення числа навчальних курсів у єпархіальних училищах, з метою їх наближення до навчальних програм жіночих гімназій.

BIBLIOGRAFIA

\section{Źródła}

Российский государственный исторический архив:

Zesp. 802, inw. 8, sygn. 24618

Zesp. 802, inw. 10, sygn. 57

Zesp. 802, inw. 10, sygn. 76

Zesp. 802, inw. 10, sygn. 101

Zesp. 802, inw. 11, sygn. 20

Zesp. 802, inw. 11, sygn. 80

\section{Opracowania}

Драч О.О., Розвиток початкової освіти в Україні (1861-1917 рр.), Charków 2001.

Днепров Э.Д. , Среднее женское образование в России. Учебное пособие, Moskva 2009.

Ежегодник правил приема и программ всех учебных заведений. 1900-1901 учебный год.

Вып. 23: Епархиальные женские училища, Sankt Petersburg 1899.

Извлечения из представленных епархиальными преосвященными святейщему Синоду соображений советов епархиальных женских училищ, по вопросу об изменениях, желательных в строе этих училищ, Sankt Petersburg 1906.

Капралова Е., О новой задачи для епархиальных училищ, „Церковный вестник” 1904, 35. Котлова Т.Б., Социокультурная среда в российском провинциильном городе в конце ХІХ начале XX века: гендерный аспект, Iwanowo 2001.

${ }^{27}$ РГИА, zesp. 802, inw. 11, sygn. 80, k. 76-93. 
Кучерова С., Загальноосвтній аспект програм духовних навчальних закладів (аналіз статутів 60-х рp. XIX ст.), „Сіверянський літопис" 2003, 4.

Об училищах девиц, духовного звания, Sankt Petersburg 1866.

Определение Св. Синода от 3-10 июля 1896 года, „Церковные ведомости” 1896, 29.

Определение Св. Синода от 6-28 сентября 1895 года за № 2689, „Церковные ведомости” $1895,40$.

Определение Св. Синода от 10-11 октября 1907 г. за № 6394, о Высочайшем утверждении положения о седьмом дополнительном педагогическом классе при епархиальных женских училищах, „Церковные ведомости” 1907, 41.

Определение Св. Синода от 20 декабря 1905 г. за № 6599, по поводу коллективных заявлений воспитанниц некоторых епархиальных женских училищ, „Церковные ведомости" 1906, 1.

Определение Св. Синода от 20-22 декабря 1905 года за № 6598, по делу о преобразовании епархиальных женских училищ, „Церковные ведомости” 1906, 1.

Определение Св. Синода от 23 августа - 5 сентября 1907 года, „Церковные ведомости” $1907,36$.

Определение Св. Синода от 30 июля - 12 августа 1886 года, „Вера и разум” 1886, 17.

Полное собрание законов Российской империи, t. 18, Sankt Petersburg 1843.

ПСЗРИ, t. 43, Sankt Petersburg 1868.

Попова О.Д., Петиции воспитанников духовной школь как выражение общественной мысли в годы первой русской революичии, „Вестник Саратовского государственного социально-экономического университета" 2007, 17 (3).

Семенов Д., Епархиальные женские училища за первое пятидесятилетие их существования, „Русская школа" 1893, 9-10.

Филевский, K вопросу о преобразовании нынешнего епархиального женского училища, „Южный край” 3 X 1905.

Чего можно желать от епархиальных женских училищ, „Церковный вестник” 1904, 52, С. $1649-1650$.

Чижевский И., Харьковское епархиальное училище в пятидесятый год его существования, Charków 1904.

\section{ABSTRACT}

There was analyzed the educational process and its dynamics during the second half of $19^{\text {th }}$ - early $20^{\text {th }}$ centuries. We note that the educational process of the eparchial schools was under the influence of sociocultural and political factors. For the the first time there was investigated the statute of the eparchial schools from 1915.

Key words: history of education, schools for clergy girls, eparchial women's school, educational process 
Proces nauczania w prawosławnych diecezjalnych szkołach żeńskich w Imperium Rosyjskim (druga połowa XIX i na początku XX wieku)

STRESZCZENIE

Artykuł stanowi analizę procesu nauczania w prawosławnych diecezjalnych szkołach żeńskich i jego przemiany w drugiej połowie XIX i na początku XX w. Okazuje się, że proces nauczania w szkołach diecezjalnych znajdował się pod silnym wpływem czynników politycznych, społecznych i kulturowych. Przeanalizowano projekt statutu szkół diecezjalnych z $1915 \mathrm{r}$.

Słowa kluczowe: historia oświaty, szkoła dla dziewcząt ze stanu duchownego, diecezjalna szkoła żeńska, proces nauczania

\section{ПРИМІТКА ПРО АВТОР}

Світлана Нижнікова - аспірантка історичного факультету Харківського національного університету імені В.Н. Каразіна, s.v.nyzhnikova@karazin.ua, +380664451260, історія освіти, жіноча історія. 